\title{
Representing a Layered Community: James, Lampson P., and Hoyt Sherman and the Development of Des Moines, 1850-1900
}

\author{
WILLIAM M. FERRARO
}

THE PEOPLE WHO SETTLED DES MOINES, like those who settled virtually every town in Iowa and the rest of the United States, began with grand expectations. They anticipated great things for both their community and their private interests. An overview of Des Moines's development from 1850 to 1900 suggests that their aspirations were fulfilled. The community's population rose from 502 to 62,139 . City boundaries expanded through annexation of abutting settlements. Des Moines emerged as the central place in Polk County, the state capital and most important city in Iowa, and a place of consequence in the Midwest. The bulky antiquarian volumes published between 1874 and 1911 that chronicle this record of achievement suggest that individual aspirations were likewise fulfilled. Through heroic individual exertion and enthusiastic cooperation, by these accounts, nearly all of the sturdy pioneers who came to the forks of the Raccoon and Des Moines Rivers overcame occasional setbacks to prosper, help build a city from a United States army fort, and die content. ${ }^{1}$

The research for this article was funded in part by a research grant from the State Historical Society of Iowa.

1. Mrs. Netti Sanford, Early Sketches of Polk County, Iowa (Newton, 1874); J. M. Dixon, Centennial History of Polk County, Iowa (Des Moines, 1876); The History of Polk County, Iowa ... (Des Moines, 1880); Will Porter, Annals of Polk County,

THE ANNALS OF IOWA 57(Summer 1998). CThe State Historical Society of Iowa, 1998. 
The story is, of course, more complicated. Widely varying levels of success could be found even among settlers who came with advantages of financial resources and family ties. The layers of Des Moines society are conveniently represented by the members of one prominent family. Their treatment in the existing histories reveals how those layers are often obscured.

James, Lampson P., and Hoyt Sherman emigrated from Ohio to Des Moines during the community's pioneer phase. All three had been born in Lancaster, Ohio, a prospering town in the southeastern quarter of the state. Their father, Charles R. Sherman, member of a notable Connecticut family, had risen to prominence as a lawyer, eventually securing a seat as a justice on the Ohio Supreme Court. Though greatly esteemed for his legal attainments and personal qualities, Charles R. Sherman shouldered a heavy burden of debt from a change in governmental monetary policy that occurred during his tenure as collector of internal revenue. His sudden death in 1829 cast his refined and educated wife, Mary, and their children from relative comfort to straitened circumstances, and the children were scattered among relatives and friends for their care and upbringing. While never quite on the brink of squalor, financial worries plagued the Shermans for decades, and an ancestral legacy of achievement put pressure on each member of the unsettled family to accomplish something significant during their life. ${ }^{2}$

Though the first of the brothers to settle in Iowa, James (1814-1864) does not merit a separate biographical sketch in any of the existing local histories. He appears only as an early merchant and jovial companion who promoted the town of Sevastopol south of the original Fort Des Moines. Lampson P. (1821-1900), known as "Lamp," typically receives a separate

Iowa . . (Des Moines, 1898); L. F. Andrews, Pioneers of Polk County, Iowa, and Reminiscences of Early Days, 2 vols. (Des Moines, 1908); Johnson Brigham, History of Des Moines and Polk County, 2 vols. (Chicago, 1911). For a more recent and sprightly treatment in the same interpretive vein, see George Mills, Looking in Windows: Surprising Stories of Old Des Moines (Ames, 1991). See also A. T. Andreas, Illustrated Historical Atlas of the State of Iowa (Des Moines, 1875); various issues of Des Moines newspapers, 1860-1900; and Des Moines city directories, published periodically, 1866-1900.

2. John F. Marszalek, Sherman: A Soldier's Passion for Order (New York, 1993), $1-6$. 
biographical sketch, invariably highlighting his brief career as editor of the Fort Des Moines Gazette. After three years with the newspaper, he became involved in banking and local government and spent the greatest portion of his working life as a politically appointed employee of the federal Internal Revenue Service, retiring in 1884. Hoyt (1827-1904) contributed to some of the antiquarian histories and generally receives considerable attention. From his quaintly humble arrival in Des Moines from Oskaloosa in May 1848, ${ }^{3}$ Hoyt, in these accounts, rose to civic prominence through steady efforts in law, banking, real estate, and insurance. Along the way, besides being a founder of Equitable Life Insurance of Iowa in 1867, he was largely responsible for post office buildings, business blocks, the Des Moines Water Company, and cultural institutions such as the Old Settlers' Association and the Iowa Industrial Exposition Company. Service as army paymaster during the Civil War earned him the title "Major" and added to his prestige. Each Sherman brother married, and their wives, never portrayed at length, receive plaudits for their domestic and social virtues. The Shermans who settled in Des Moines did not achieve the fame of their brothers William Tecumseh (1820-1891), the Civil War general, or John (1823-1900), the influential Republican politician and United States senator, but according to antiquarian and more recent popular histories they led respectable lives and did more than their share of good."

Looking at the lives of James, Lampson P., and Hoyt Sherman in greater depth, however, reveals much about the structure of Des Moines as it developed between 1850 and 1900. The experiences of each brother represent an identifiable "layer" within the community. Hoyt, outwardly the most successful, represents the "entrepreneurial" layer, the cohort of business leaders and aggressive risk takers with high economic and often social aspirations. To capture the intense

3. Hoyt Sherman, "From Oskaloosa in a Wagon," Annals of Iowa 33 (1956), 281-88; his account was originally published in 1898 .

4. Besides the titles listed in note one, see George S. Mills, The Little Man with the Long Shadow: The Life and Times of Frederick M. Hubbell (Des Moines, 1955); and George Sexton Pease, Patriarch of the Prairie: The Story of Equitable of Iowa, 1867-1967 (New York, 1967). 
competitiveness among this relatively small group, and the potentially dire consequences of failure for any member, Hoyt must be considered in connection with those who shared his drive for wealth and civic leadership. Lampson, whose profile in Des Moines diminished over the years, represents the "burgher" layer, those who sought stability and comfort rather than spectacular wealth and were willing to commit time and energy to their neighborhood and local institutions. Burghers tend to be steady, cautious, and most involved in municipal government. James, who suffered from alcoholism and whose impress on Des Moines faded quickly, represents the "dispossessed" layer, the less visible people out of step with prevailing social or economic norms. The dispossessed could be suffering from physical or emotional ailments, caught in a cycle of debt, or burdened by bias or prejudice. The dispossessed have limited opportunities and provoke scorn, fear, or sympathy among the burghers and entrepreneurs.

In Des Moines each layer remained largely self-contained and discrete. There appears to have been little volatility or interaction among entrepreneurs, burghers, and the dispossessed. Supportive contact or keen competition took place principally within each layer, and little or no movement occurred upward or downward among the layers. ${ }^{5}$ Significantly, political leaders, even those in the vaunted Des Moines Regency, evidently maintained no sustained or substantial relationships with the entrepreneurs who pushed the economic growth of the city. ${ }^{6}$ Without meaningful cooperation between business and political elites, it is difficult to fit Des Moines within a "booster" model of urban development.

5. For similar lack of mobility in Omaha between 1880 and 1920, see Howard P. Chudacoff, Mobile Americans: Residential and Social Mobility in Omaha, 1880-1920 (New York, 1972), 102.

6. See, for example, Johnson Brigham, James Harlan (Iowa City, 1913); Dan Elbert Clark, Samuel Jordan Kirkwood (Iowa City, 1917); Edward Younger, John A. Kasson: Politics and Diplomacy from Lincoln to McKinley (Iowa City, 1955); Leland L. Sage, William Boyd Allison: A Study in Practical Politics (Iowa City, 1956); Thomas Richard Ross, Jonathan Prentiss Dolliver: A Study in Political Integrity and Independence (Iowa City, 1958); Mildred Throne, Cyrus Clay Carpenter and Iowa Politics, 1854-1898 (Iowa City, 1974); and Robert Cook, Baptism of Fire: The Republican Party in Iowa, 1838-1878 (Ames, 1994). 


\section{THE ANNALS OF IOWA}

That booster model, which emphasizes practical cooperation among ambitious individuals or groups to secure gain for all along with civic progress, has long been popular among academic historians in the United States, as well as amateur local historians. Stressing mutual dependence among city residents and consensus over competition, the model accommodates uneasy collaboration or tenuous compromise as the social and economic composition of a locale diversifies and balancing diverging group imperatives becomes a growing challenge.? In opposition to the booster model, other historians have tended to view urban development principally as the result of individuals acting in relative isolation. Private interests and personal preference essentially divorced from public spiritedness or unity motivate individual behavior and shape communal outcomes. ${ }^{8}$ Yet another approach has emerged as recent historians have examined locales from an increasingly inclusive perspective to discover what gave a place economic, political, or social cohesiveness and an overarching character. Perhaps the most widely known and highly regarded of these works is William Cronon's explication of Chicago's development as "an expanding metropolitan economy creating ever more elaborate and intimate linkages between city and country." Mary P. Ryan argues that through open and volatile expression in public spaces, people in New York, New Orleans, and San Francisco created viable civic identities despite cultures that were "full of cultural differences" and "fractured by social and economic changes. ${ }^{\prime \prime 9}$

7. See, for example, Richard C. Wade, The Urban Frontier: The Rise of Western Cities, 1790-1830 (Cambridge, MA, 1959), 105-7, 203; Robert R. Dykstra, The Cattle Towns (New York, 1968); and Don Harrison Doyle, The Social Order of a Frontier Community: Jacksonville, Illinois, 1825-1870 (1978; reprint, Urbana, 1983). For a persuasive revision of the booster model, see Robin L. Einhorn, Property Rules: Political Economy in Chicago, 1833-1872 (Chicago, 1991), 18, 29, 142-43, 225-27.

8. See, for example, Frederick Jackson Turner, "The Significance of the Frontier in American History," in The Frontier in American History (1920; reprint, New York, 1962); Sam Bass Warner Jr., The Private City: Philadelphia in Three Periods of Its Growth (Philadelphia, 1968), 3-4; and Roger W. Lotchin, San Francisco, 1846-1856: From Hamlet to City (New York, 1974), 345-46.

9. William Cronon, Nature's Metropolis: Chicago and the Great West (New York, 1991), xv; Mary P. Ryan, Civic Wars: Democracy and Public Life in the American 
Too often lost in portrayals of town and urban development are the experiences of individuals as they strove to make something of their lives. To fully understand these processes the historian must bring to light real people as well as plausible analytical frameworks. ${ }^{10}$ Recovering individual lives can be a formidable challenge. Only through research in property and probate records, contemporary newspapers and manuscript letters, census returns, and city directories can one reconstruct the lives of the three brothers who so well represent the layered communities in Des Moines between 1850 and 1900.

IN 1846, after suffering reverses in Ohio and declining an offer from Charles Taylor Sherman, the oldest Sherman brother, to enter business in Mansfield, James determined to try the nascent settlement at Fort Des Moines. ${ }^{.1}$ He left Ohio in late spring with $\$ 35$ and a letter of credit for another $\$ 100$ payable in St. Louis from his brother Tecumseh, who remarked confidently,

City during the Nineteenth Century (Berkeley, 1997), 3, 302. See also Philip J. Ethington, The Public City: The Political Construction of Urban Life in San Francisco, 1850-1900 (Cambridge, 1994), 8-9, 14; Timothy R. Mahoney, River Towns in the Great West: The Structure of Provincial Urbanization in the American Midwest, 1820-1870 (Cambridge, 1990); idem, "Down in Davenport: A Regional Perspective on Antebellum Town Economic Development," Annals of Iowa 50 (1990), 451-74; Kay J. Carr, Belleville, Ottawa, and Galesburg: Community and Democracy on the Illinois Frontier (Carbondale, IL, 1996); William Issel and Robert W. Cherny, San Francisco, 1865-1932: Politics, Power, and Urban Development (Berkeley, 1986); and Jon C. Teaford, Cities of the Heartland: The Rise and Fall of the Industrial Midwest (Bloomington, IN, 1993).

10. Historical works concerned with communal issues but emphasizing individual lives include Gerald W. McFarland, A Scattered People: An American Family Moves West (New York, 1985); John Mack Faragher, Sugar Creek: Life on the Illinois Prairie (New Haven, CT, 1986); Nancy Grey Osterud, Bonds of Community: The Lives of Farm Women in Nineteenth-Century New York (Ithaca, NY, 1991); Lynn A. Bonfield and Mary C. Morrison, Roxana's Children: The Biography of a Nineteenth-Century Vermont Family (Amherst, MA, 1995).

11. Writing to his mother in September 1839, Tecumseh Sherman, then a cadet at West Point, remarked sarcastically that success had come to his older brother as a merchant in Cincinnati because of "his way of getting in with the farmers and loafers-the best customers." William T. Sherman (WTS) to Mary Sherman, 30 September 1839, William T. Sherman Papers, Library of Congress. While possibly only fraternal teasing, Tecumseh's taunt suggests that perhaps even at this early date the family knew that James had a problem with liquor. 
"[James] will have enough not to want and if he plays his cards well at this particular time he cannot but do well." Returning to Ohio for the winter of 1847, James set off again for Des Moines in April, taking $\$ 1,000$ to start a grocery. He departed in "fine spirits" at the prospect of "starting again in business for himself." He reached Des Moines via Cincinnati (where he bought some goods) and St. Louis. Following her husband in the summer of 1847, Sophia Sherman found the comforts of Iowa wanting in comparison to those left behind in Ohio, but she endured the primitive conditions for the sake of reuniting the family, then including one son. By early 1848 , James could report reasonable success in business, the bad news being that the entire family suffered "from the disease of the Country, Fever \& Ague." ${ }^{\prime 12}$

By 1850, James and Sophia Sherman had moved from a cramped boardinghouse to their own home, and James served as the head of a household that included his wife, a son, and a daughter born since their arrival, as well as his younger brothers Lampson and Hoyt. James's census return listed the value of his real estate at $\$ 1,200$, substantially higher in value than the holdings of his nearest neighbors, the families of prominent lawyer Phineas M. Casady and influential Presbyterian minister Thompson Bird. It appears, though, that the real estate holdings masked business reverses. James evidently had failed as a grocer, and only his recent efforts inspired a measure of hopefulness from his brother Tecumseh, who commented, "Jim is much improved in habits, and is engaged in butchering for the market." By November matters had turned for the worse. James had no income, and "poor Sophia" was "talking about returning to Ohio." Tecumseh learned in a conversation with Hoyt that the situation had deteriorated further by spring 1851. "Jim still drinks—-does nothing. ${ }^{13}$

12. WTS to John Sherman (JS), 4 January and 12 June 1846; JS to WTS, 2 May 1847; Sophia Sherman to Mrs. William S. Dart, 6 July 1847, facsimile of transcription held privately; Mary Elizabeth Sherman Reese to WTS, ? February 1848, Sherman Papers.

13. 1850 Manuscript Federal Census, Polk County, Iowa; Andrews, Pioneers of Polk County, 1:17, 27; WTS to JS, 12 August and 12 November 1850, 11 June 1851, Sherman Papers. 
James and the entire Sherman family faced a predicament in February 1852 when Sophia apparently threatened to divorce her husband and return to her relatives in Ohio. Tecumseh informed John of his attempts to mend the breach but recognized the limits of his efforts. "I have written to Hoyt to dissuade Sophia from going to Ohio, where her presence will only embarrass her own family or ours-She must look in part to her own exertions for support and these will be more available at Des Moines than in Ohio-I have also written to Jim \& Sophia, both in Such terms as seem to me best to prevent an irrevocable separation but if Jim wont stop his drinking Sophia has no alternative." John had lost patience with James and vented anger in his reply. "The affair of Jim \& Sophia is truly deplorable. It is shameful. Jim is so far lost to all sense of Honor that I will do nothing for him. He had as good a chance to make himself independent in Des Moines as any man ever had. He took with him from here $\$ 1,000$ which he knew he could use as long as he wanted it and by investing it with ordinary prudence might now be worth $\$ 10,000$. He . . . spent all his money sold his lots \& became a miserable drunkard. What poor Sophia can do or what she had better do God only knows." James and Sophia somehow patched up their marriage, but their fortunes did not improve appreciably. Four years later, in 1856, forty-year-old James Sherman reported to state census takers that he headed a household including only his immediate family, increased by another son, then five years old. He identified himself as a merchant, native voter, militia member, and the owner of 150 unimproved acres. His neighbors were a blacksmith born in Ohio who owned 100 unimproved acres and a tinner born in New York who reported no property holdings. ${ }^{14}$

During his first decade in Des Moines, besides working as a merchant and upsetting his family with drinking binges, James bought and sold property in and near the town. He made his two most important purchases on February 13, 1854, when he procured a dwelling lot on the corner of Second Street

14. WTS to JS, 12 February 1852; JS to WTS, 29 February 1852, ibid.; 1856 Manuscript Iowa State Census, Polk County. 


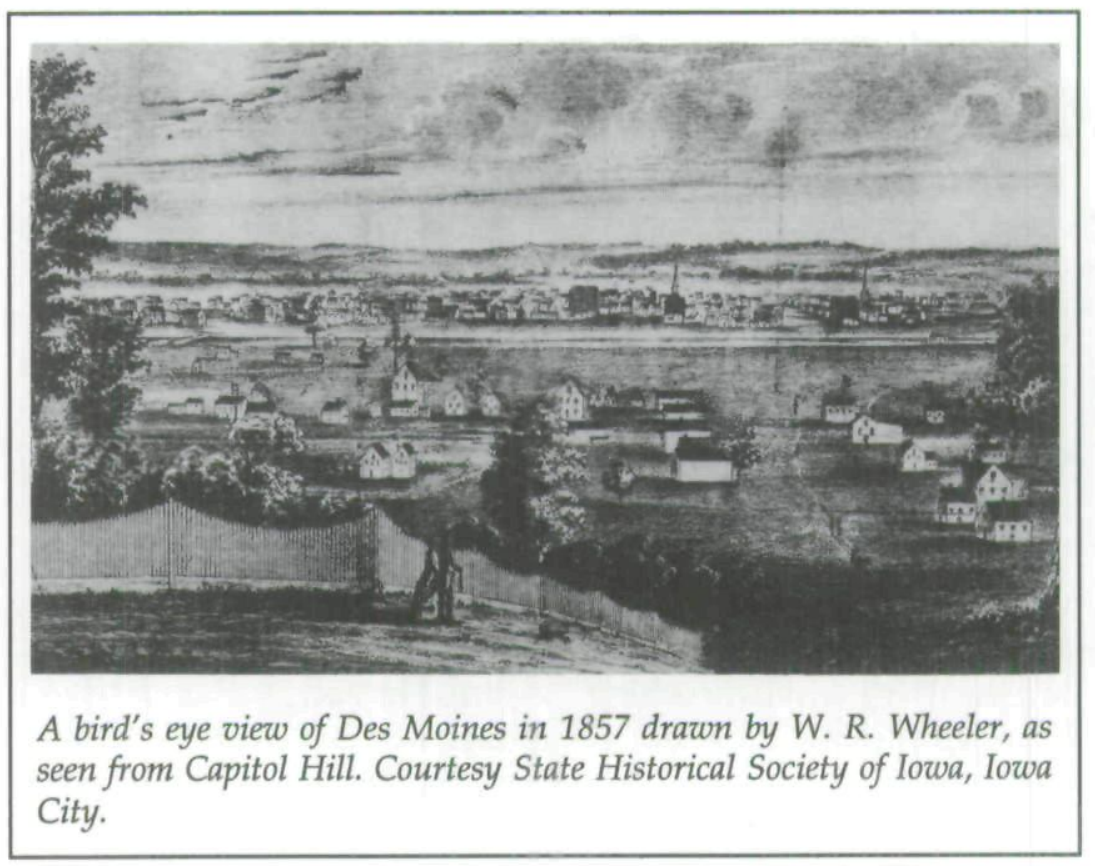

and Court Avenue for $\$ 250$ and an approximately fifty-acre unimproved tract directly south of the town for $\$ 350$. He had this latter tract platted into one-acre lots and hoped that the area would develop into a village, which he named Sevastopol. Those lots did not sell over the next few years, but James accrued some income from property by selling other parcels. He did realize a nominal profit of $\$ 750$ on the dwelling lot when he sold it for $\$ 1,000$ in 1859 , a gain that must have been welcome due to the prolonged depression following the Panic of 1857 and the fact that a speculative windfall had not come his way. By 1860, however, James was in financial straits. He considered himself a clerk rather than a merchant, and despite owning $\$ 20,000$ in real estate, he claimed only $\$ 150$ in personal property. His family, with their property and a domestic servant, must have seemed badly out of place in a fluid workingclass neighborhood composed primarily of Irish immigrants, day laborers, and saloonkeepers. ${ }^{15}$

15. Polk County Archives, Property, G:269-70, 3:123-24, B:284, E:56, 74, K:205; 1860 Manuscript Federal Census, Polk County. 
James's property transactions reveal additional problems. In 1852, and again in 1859, he and Sophia placed land parcels in trust with Hoyt Sherman for the benefit of their children. This could be interpreted as benevolence except that a pattern of mortgaging property for cash and evidence of several years' taxes in arrears indicate that James suffered from deficient cash flow and debt. The situation reached a crisis on June 29, 1863 , when James quitclaimed to Sophia for $\$ 200$ all right, title, and interest to the family homestead. This legal maneuver put that property beyond the reach of his creditors. (Earlier, probably for a similar reason, Sophia transacted property business on her own, unusual for a married woman at that time.) In July and August 1863, James and Sophia raised almost $\$ 450$ by selling lots in Sevastopol, but that income evidently did not relieve pressing debts. ${ }^{16}$

Later that year, John Sherman, then United States Senator from Ohio, arranged to have James moved to Cincinnati, where he could be supervised by a brother-in-law overseeing the manufacture of war materials. This relative found James a job in a tent factory, but he was unable to keep his charge from the bottle. On July 10, 1864, James died in Cincinnati from the effects of alcoholism. On July 29, Tecumseh Sherman, poised with his army outside Atlanta, wistfully ended a long letter to his wife on military matters, "Poor Jim. He was a good fellow, but John Barleycorn was too much for him. ${ }^{\prime \prime 7}$

A brief death notice about James Sherman in a Des Moines newspaper smoothed over his move to Cincinnati as being required by "business arrangements" and lamented the demise of a "noble hearted man." His widow and son Charles remained in Des Moines and raised money over the next few years by selling property in Sevastopol and around Des Moines, the last sale occurring in July 1866. Sophia lived at the homestead, on the north side of Mulberry between Sixth and Seventh, in what had become an unfashionable part of the city, until her

16. Polk County Archives, Property, F:5, D:8, D:114, G:445, 468, 488, 489, M:430; Mortgages, C:547, F:44.

17. Williams' Cincinnati Directory, ... June, 1864, 32; JS to WTS, 12 July 1864, Sherman Papers; WTS to Ellen E. Sherman, 29 July 1864, Sherman Family Papers, University of Notre Dame. 
death on September 7, 1871. Whatever promise and hope she had felt upon coming to Des Moines almost twenty-five years earlier almost certainly had been dashed long before by anxiety, heartache, and struggle..$^{18}$ Certainly, many others among the dispossessed, whose lives and travails are nearly impossible to delineate at any length, felt the same painful emotions.

LAMPSON P. SHERMAN likewise experienced sorrow in Des Moines, but he overcame it to establish himself as a solid, middle-class citizen-a burgher. In the early 1840 s, he worked for the Cincinnati Gazette, mostly as a rather humble typesetter. Unsatisfied with his situation, Lampson considered relocating to New Orleans, but he instead remained in Cincinnati, attempting to augment his income by investing his modest savings in a "small grocery \& produce stand." His decision to stay in Cincinnati may have been connected to his marriage in 1845 and the birth of a son in 1846. Following the death of his wife in 1848, Lampson, tired of relentless and largely unremunerative toil, decided to move to Des Moines, where he could fulfill his aspiration of editing a newspaper. ${ }^{19}$

He arrived in Des Moines in 1849 and concentrated all his energy on launching his newspaper. The first issue of the Fort Des Moines Gazette nominally came out on January 1, 1850, but the earliest surviving issue is dated January 18. Presenting himself as "EDITOR AND PROPRIETOR," Lampson apologized for the issue's tardiness and promised henceforth to "furnish a paper, so far as mechanical execution and appearance is concerned, every way worthy of public patronage." He also forthrightly stated his political sentiments and editorial principles. "In politics it will be decidedly WHIG. Its editor has been reared in a school which knows of no compromise. ... But ... the paper shall never become the vehicle of private abuse or personal slander. A due regard shall be paid to the conscien-

18. Iowa State Register, 21 and 22 July 1864 and 9 September 1871; Polk County Archives, Property, H:283-84, 629-30, I:179, 453-54, 457-58, 546, M:358, O:105-6, 107-8, S:489, 1:268; Mortgages, G:278, 573-74, 577.

19. WTS to JS, 16 October 1843 and 19 January 1844; JS to WTS, 2 May 1847, Sherman Papers. 
tious opinion of others, and he will always endeavor to counteract opposition by argument and persuasion, satisfied that in this age freedom of thought may be tolerated, while truth is left free to combat whatever is erroneous." The paper, he promised, would not be "a mere political paper. Agriculture, Literature, Science, and the development of the resources of the Great West will have their proper share of attention." Lastly, he announced that since he had, "by the investment of his entire capital, identified himself with the citizens of the Des Moines Valley, he will never prove recreant to their interests, or be backward when they can receive advantage from his efforts. The 'Gazette' will be published permanently-of this the public need have no fears. ${ }^{120}$

Lampson was true to his word in some respects. Subsequent issues of the paper called for free ferries over the rivers to bring more outlying farmers to the local market, publicized a meeting of local citizens promoting construction of a railroad from Davenport to Council Bluffs via Fort Des Moines, and cheered the arrival of foreign immigrants. "Come, we say, one and all-come from oppressed Ireland, downtrodden Hungary, and unfortunate Poland-come from everywhere, ye oppressed of every nation, name, kindred and tongue-come to our free and fertile State. We bid you welcome. ${ }^{121}$ Lampson, however, could not keep the paper solvent, jeopardizing his bold assertion of permanence. His hardship elicited sympathy and some tangible support from his family. Writing in July 1850, Tecumseh urged John to "try and keep up Lamp's spirits by a line occasionally." In August of the same year, Lampson's mother gave him additional time to pay back a loan. In November, Tecumseh wrote to John that "Lamp is as usual hard up to meet some note for the printing press," adding that his own needs meant he could not "step in and offer aid."

20. Fort Des Moines Gazette, 18 January 1850 . Hoyt Sherman, then the Des Moines postmaster, helped his brother with the inaugural issue by running an advertisement announcing the "Arrival and Departure of Mails."

21. Ibid., 25 January and 1 February 1850.

22. WTS to JS, 1 July, 12 August, and 12 November 1850, Sherman Papers. In September 1850, Tecumseh wrote to John that he would counsel Lampson "to persevere in his establishment at Des Moines." WTS to JS, 7 September 1850 , ibid. 
Lampson broadcast his plight in January 1851, asking subscribers to pay up. "We are sorely in want of our money and must have it. It is our purpose to close up the affairs of the Gazette at the expiration of No. 52. . . We can no longer publish a paper and find ourselves." He soon after relieved his most pressing debts by selling part of his interest in the paper, a transaction that left him engaged in the concern but resulted in a new proprietor and name for the publication. ${ }^{23}$ In early August 1852, still struggling with the newspaper, Lampson pursued political appointment as register of the proposed Des Moines land office, seeing that post as ballast to keep his enterprise underway. Tecumseh eagerly assisted his machinations, but a crushing Whig defeat in the 1852 presidential election surely ended any remaining hopes Lampson may have had. ${ }^{24}$

Failure to secure additional means, and marriage on December 31, 1851, to Susan Lawson, oldest daughter of a local wool carder in modest circumstances, probably influenced Lampson's decision to finally jettison the underfunded newspaper. By the time of his marriage, Lampson had dabbled in local property and earned enough respect among his fellow citizens to be placed on the committee that drafted the first town charter as well as to be chosen for the first town council. Lampson enhanced his position after selling the newspaper. He worked as a land agent and then as bookkeeper in his brother Hoyt's banking ventures. He served in local office as mayor, recorder, and treasurer, all the while judiciously buying, selling, and mortgaging property on his own account. In 1860 Lampson, engaged in bookkeeping, headed a household with his wife, two young sons, and his wife's younger sister. He owned $\$ 5,000$ in real estate and $\$ 500$ in personal property. ${ }^{25}$

23. Fort Des Moines Gazette, 24 January 1851; WTS to JS, 11 June 1851, Sherman Papers. The Iowa State Journal (P. Myers \& Co., proprietors), first appeared on February 28, 1851.

24. WTS to JS, 19 August 1852, Sherman Papers.

25. Polk County Archives, Property, E:120, 152, 150, F:55, 58, 60, 132, 230, 507, G:181, A2:636, H:487; Edward H. Stiles, Recollections and Sketches of Notable Lawyers and Public Men of Early Iowa (Des Moines, 1916), 469; 1850 and 1860 Manuscript Federal Censuses, Polk County; 1856 Manuscript Iowa Census. 


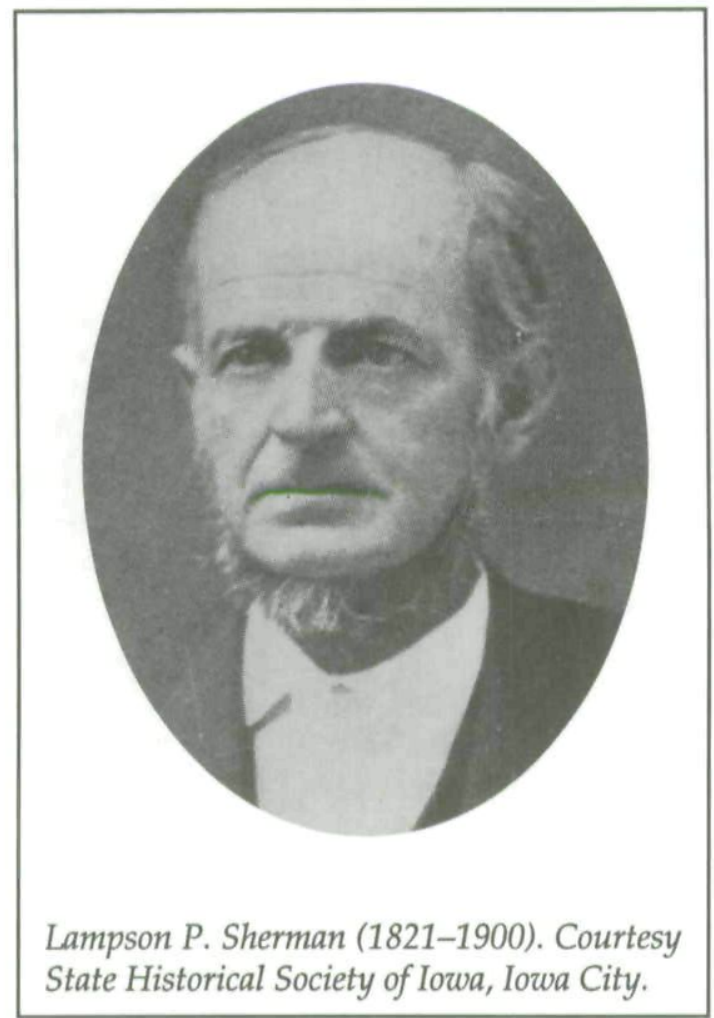

Tragically, Lampson and his wife lost a son in 1854 and a daughter in 1855. The family lost two more sons in 1863 and another in 1867. These deaths seem to have dulled Lampson's ambition. His property transactions after 1857 became much less frequent and much more conservative. He contented himself as a bookkeeper until February 1867, when President Andrew Johnson rewarded him for political loyalty with an appointment as collector of Internal Revenue for Iowa's Fifth District. His appointment came after the Republican Senate had rejected the nomination of a Democrat. Lampson remained in this post until he retired in 1884 with a Democratic presidential administration on the horizon. ${ }^{26}$ During those

26. Timely intervention by his brothers Tecumseh and John saved Lampson from ouster just after the start of Ulysses S. Grant's second term as president. "I have just seen the President," wrote Tecumseh, "and explained to him the 
years he served stints as an alderman-a rather thankless post responsible for addressing complaints about streets, drains, and the like-and was among the original investors in Equitable Life Insurance of Iowa. On the whole, however, he remained in the background, unwilling to compete with ambitious and aggressive business contemporaries, and focused on maintaining his family. ${ }^{27}$

Two sons and a daughter from Lampson's second marriage grew to adulthood. He spent his lengthy retirement manipulating his few property assets to bolster his older son's efforts to operate a real estate agency in Des Moines, getting his daughter settled as a teacher in the local schools, and waiting for his other son to find his way through a succession of false starts before becoming a firefighter. By 1886, Lampson had purchased property from Hoyt in the pleasant suburban area known as University Park and moved his household there. Lampson died in 1901 after a lengthy illness. Honored as an "efficient officer" and deemed "much liked and popular" in an obituary that failed to mention the five deceased children, Lampson's probate shows that he died without debt. The four surviving children (including one from Lampson's first marriage) assigned their interests in the estate to the widow, and she apparently lived in comfortable circumstances until her death in $1905{ }^{28}$ Reliable, conscientious, unspectacular burghers such as Lampson P. Sherman provided Des Moines with a firm foundation for growth through its first decades.

removal of Lamp. He assured me that he knew nothing of it whatever, \& only signed the papers presented to him by the Dept... [and that] he would recall the nomination." WTS to JS, 15 March 1873, Sherman Papers. On March 13, 1873, Grant had nominated Cole Noel to replace Lampson Sherman as collector of Internal Revenue; on March 17, Grant withdrew Noel's nomination. Senate Executive Journal, 43d Cong., special sess., 1873, 19:55, 57, 72.

27. Polk County Archives, Property, H:153, I:23, K:165, 229, O:200-202, 27:189-90; Senate Executive Journal, 39th Cong., 2d sess., 1866-67, 15, pt. 1:212; Lampson P. Sherman Family gravestones, Woodland Cemetery, Des Moines. 28. Polk County Archives, Property, 101:479, 119:554-55, 127:86, 164:59, 65, 248:119; Bushnell's Des Moines Directory, 1889-90 (Des Moines, 1889), 444-45; R. L. Polk \& Co.'s Des Moines City ... Directory, 1894 (Des Moines, 1894), 584; ibid., 1897 (Des Moines, 1897), 518; ibid., 1902 (Des Moines, 1902), 750; Des Moines Leader, 22 November 1900; Des Moines Register and Leader, 31 December 1905; Lampson Sherman Probate, \#4238, Polk County Genealogical Society. 
HOYT SHERMAN, unlike Lampson, never limited himself to the role of modest burgher. He came to Iowa with an entrepreneurial temperament, intent on securing pecuniary gain and personal stature, and he pursued those ends unceasingly. Although Hoyt's older brothers Tecumseh and John playfully chided him as a youth, those same brothers took a genuine interest in his career and supplied occasional advice. Despite their goodwill and concern, Hoyt still shouldered the heaviest burden for charting his future. ${ }^{29}$ Unhappy with the prospect of advancing as a printer in Cincinnati only by apprenticing to a journeyman, Hoyt considered joining James in Des Moines during the fall of 1847 to study law or go into the mercantile business, but he chose instead to enter the law office of his brothers John and Charles in Mansfield, Ohio. ${ }^{30}$ Fortified with a scant year of legal training, twenty-one-year-old Hoyt headed west in the summer of 1848 .

Arriving at Fort Des Moines, Hoyt allied with Phineas M. Casady and Robert L. Tidrick, lawyers heavily involved with land sales and town expansion. Hoyt carried his weight and then some, negotiating land deals, managing construction projects (including the first post office building and business block), and establishing a bank. On his own, Hoyt briskly engaged in the real estate market, buying and selling parcels and lending money on mortgaged land. He apparently dealt with people on both sides of the Des Moines River, despite his ostensible connection with "West Siders" in the acrimonious dispute over the placement of the state capitol and other public buildings. ${ }^{31}$ Known first as a Whig and then as a Republican

29. For youthful chiding, see WTS to JS, 7 March 1840 . When Hoyt was working with Lampson on the Cincinnati Gazette, Tecumseh wrote to John, "Keep your Eye on Hoyt and dissuade him if possible into some more agreeable business than that of Printer." WTS to JS, 4 January 1846. But for Tecumseh's recognition that Hoyt must decide for himself on a career, see WTS to JS, 12 June 1846. All three letters are in Sherman Papers.

30. JS to WTS, 2 May 1847; Mary Elizabeth Sherman Reese to WTS, ? February 1848, Sherman Papers.

31. For materials related to the official investigation of this notorious incident in the annals of Des Moines, see Minutes and Reports, Special Committee to Investigate Charges of Fraud in Locating the Capitol, Secretary of State, Legislative 7th G. A., State Archives of Iowa, State Historical Society of Iowa, Des Moines; 1858 Iowa House Journal, 704-8, 711-16. 
partisan, he also participated in politics, holding office at various times during this early period as district court clerk, postmaster, and council member. In late 1855 Hoyt returned to Ohio to marry Sara Moulton. She joined him in Des Moines to share in his business and social climb. ${ }^{32}$

Hoyt narrowly avoided financial disaster in the Panic of 1857 , and his survival showed the value of kin relationships. Before Iowa adopted a new constitution in 1857, banks in Iowa could not issue currency. Iowa bankers relied on the issues of other states for a circulating medium, and maintaining a healthy supply of reliable currency in that era of "wild cat banks" proved a constant challenge. For assistance, bankers around the country looked to New York City, already the center of financial exchange and the home of the soundest banking institutions. Learning in summer 1857 that his brother Tecumseh was about to locate in New York City to operate a branch of a prominent St. Louis bank, Hoyt arranged to convey a large proportion of his assets to Tecumseh's hands to facilitate his transactions in Des Moines. Less than three months later, Tecumseh wrote to John that the parent bank had failed, but before that failure carried away the New York City branch he had saved Hoyt's deposits, leaving unsaid that he almost certainly had sacrificed other depositors. "I put Hoyts money to his credit at the Bank of America, one of the best in the city. . . . I have written to Hoyt fully so that I think he will not only lose nothing by us, but also not be incommoded. ${ }^{\prime \prime 3}$ The general crash soon reached Des Moines, where only Hoyt's bank and that of prominent financier Benjamin F. Allen met the extra-

32. Obituary, Des Moines Register and Leader, 26 January 1904; Polk County Archives, Property, E:289, F:132, G:141, H:8, 393, K:3, 14, 67, 80, 444, 452, A2:264, L:207, N:620-21, B:551, C:48, 330, 634, D:129, E:302, M:280; Mortgages, B:519, C:64; Hoyt Sherman to Phineas M. Casady, 20 February 1857, Simon Casady Papers, State Historical Society of Iowa, Des Moines; Robert P. Swierenga, Pioneers and Profits: Land Speculation on the Iowa Frontier (Ames, 1968), 115-17, 124, 240. In 1851, Tecumseh reported to John that Hoyt had recently visited him in St. Louis and that Hoyt "seems well established at Des Moines-owns the little frame in which the Post office is, and Some two or three town lots." WTS to JS, 11 June 1851, Sherman Papers.

33. JS to WTS, 13 July 1857; WTS to JS, 12 October 1857. On 25 August and 7 October 1857, Tecumseh wrote to Hoyt about the financial arrangements. All correspondence in Sherman Papers. 
ordinary demands. In 1858, after the Iowa legislature authorized a state bank system under the strict provisions of the new constitution, Benjamin F. Allen and Hoyt opened the Des Moines branch, as president and cashier, respectively. ${ }^{34}$

In 1860 Hoyt reported himself to the census as a banker holding $\$ 22,000$ in real estate and $\$ 2,000$ in personal property. His household included his wife, a young son and daughter, and two female domestics, one Swedish and the other Prussian. His most notable property acquisitions had been a purchase for $\$ 45$ of two lots between what became Walnut and Locust Streets in April 1850 (site of his first home and subsequently a valuable business property) and a purchase for $\$ 115$ of a nearly five-acre lot from the Hugh Pursley estate in November 1855 (later the site of his well-known homestead, now maintained by the Des Moines Woman's Club as the Hoyt Sherman Place). Hoyt evidently enjoyed a steady stream of cash from his banking and other businesses. When he required extra money, he typically sold property for "cash in hand." His property transactions slowed during his Civil War service as an army paymaster, and he tended to sell rather than buy, his most significant sale being a portion of the "Sherman Block" to Benjamin Allen for $\$ 5,000 .^{35}$

34. For Hoyt Sherman's recollections of banking in Iowa before the Civil War, disappointingly silent on personal experiences, see "Early Banking in Iowa," Annals of Iowa 5 (1901), 1-13; and "The State Bank of Iowa," ibid., 93-116. In late 1858, Tecumseh informed John that Hoyt "seems a little tired of Banking, but if it do not involve him in utter Ruin he will have cause to be thankful." Six months later, Tecumseh again wrote to John, noting that Hoyt "seems to be a man of much weight in Iowa." WTS to JS, 8 December 1858, 27 May 1859, Sherman Papers.

35. 1860 Manuscript Federal Census, Polk County; Polk County Archives, Property, C:587, H:365, F:37-38, 128, 162, 394, G:230, 621, H:144, 261, 580-81, Q:356, S:212: Mortgages, G:31. Hoyt elaborated on his entry into the army to a business associate in New York City. He noted that his appointment as paymaster "was made without application or knowledge on my part, but after looking over the whole ground-the great depression in all kinds of business, and the prospect that it will continue for some time at least here-I have determined to accept it, and am now hurriedly arranging my affairs to enter on the duties of the office. No permanent change will be made in the Bank at present, as in the course of affairs I may be able to resume my position in six or eight months. My brother L. P. Sherman will act as Cashier for the present. I leave everything in connection with the Bank in good condition . . . and it is withal a profitable Institution to the stockholders." Hoyt 


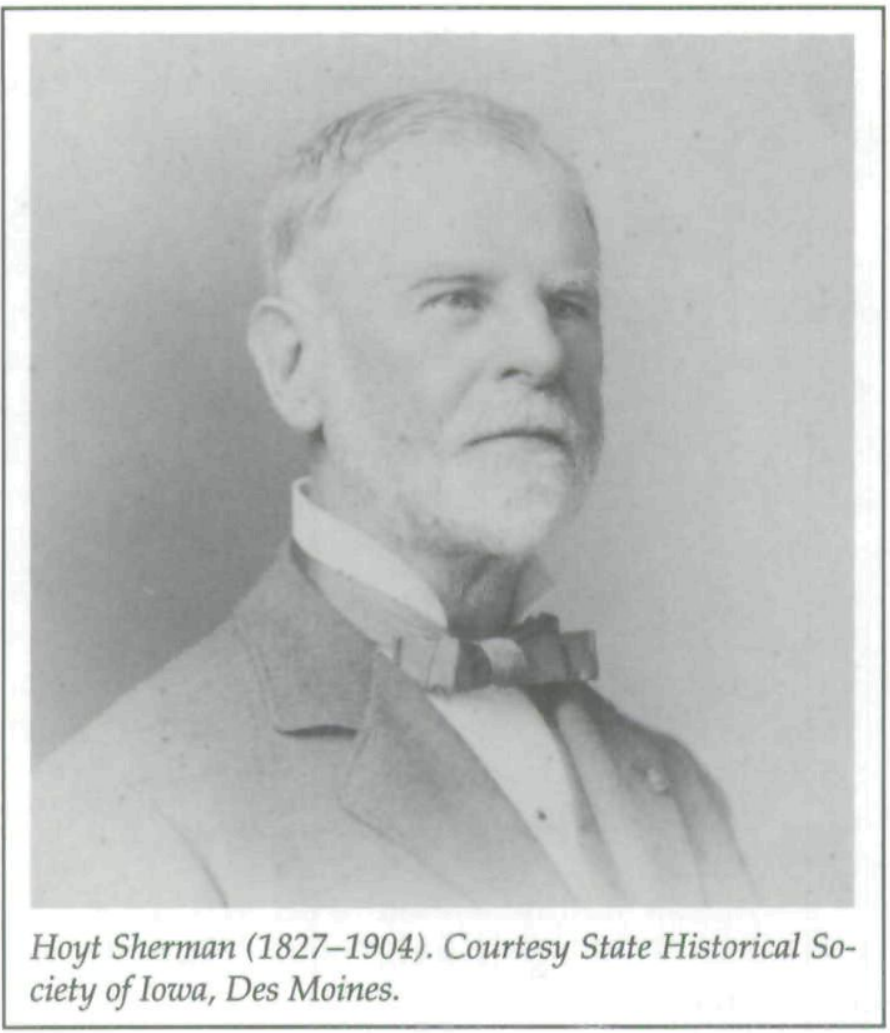

Hoyt's absence from Des Moines during the Civil War seems to have allowed his banking competitors to take his business. Upon his return, Hoyt opened a hardware store in a partnership at 38 Court Avenue. At the same time, he served a term in the General Assembly as Polk County's representative. ${ }^{36}$

Hoyt must have found little satisfaction in the legislature or among the hardware store's pots, pans, tools, and household implements, because in January 1867 he eagerly joined a group of local business elites to form Equitable Life Insurance

Sherman to Arthur Gilman, 19 September 1861, Schoff Civil War Collection, Clements Library, Ann Arbor, MI. Hoyt resigned as paymaster as of April 9, 1864. For his earliest Civil War experiences, see Hoyt Sherman, "Personal Recollections of General Grant," Midland Monthly 9 (1898), 325-27.

36. Des Moines City Directory and Business Guide . . 1866-67 (Des Moines, 1866), 38, 127, 129; 1866 Iowa House Journal, 3, 66, 69-70, 82-83, 111-12, 207-8. 


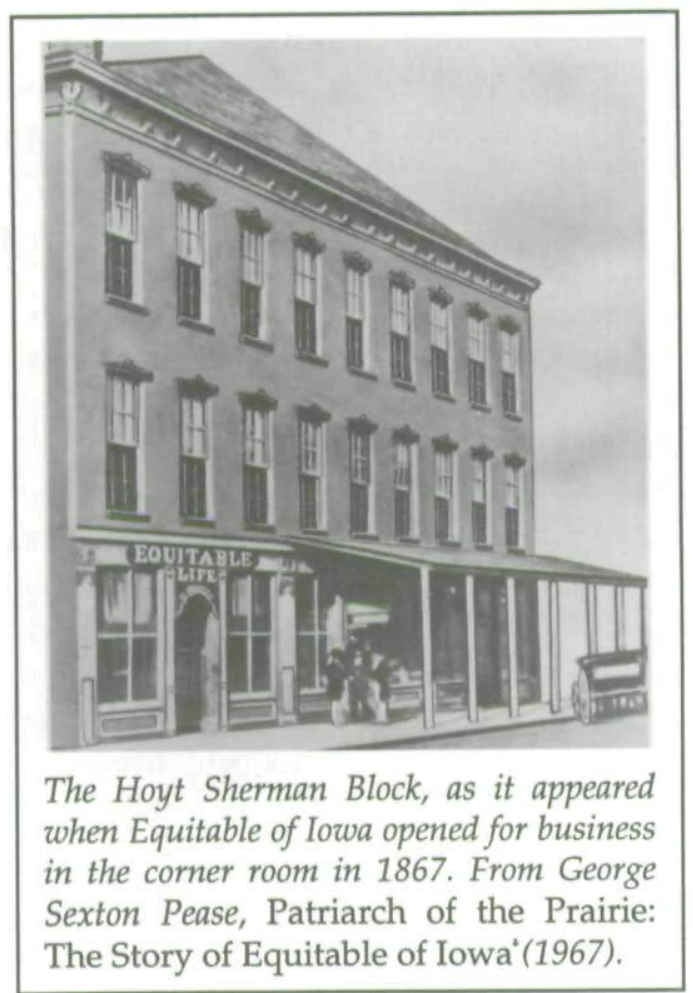

of Iowa. Due to his availability and financial if not insurance background, Hoyt became secretary of the new firm. He rose to president in 1874, and his stewardship of the successful company earned plaudits.

THE MEN WHO JOINED HOYT SHERMAN to found Equitable Life formed the mainstay of the entrepreneurial layer in Des Moines. Knowing more about them helps one understand the frenetic pace Hoyt maintained, his relative position among his contemporaries, and the stiff competition he faced in his efforts to secure advancement. All in the founding group of sixteen men had been in Des Moines for more than a decade. ${ }^{37}$

37. Persistence in a community usually denotes a high degree of success or contentedness. See, for example, Doyle, Social Order, 92-118, and Hal S. Barron, Those Who Stayed Behind: Rural Society in Nineteenth-Century New England (New York, 1984). 
They had known each other from previous business or social relations and represented a fair sample of the most economically successful residents in the city. But the cooperation they displayed in starting Equitable was only a veneer; all continued various other business and real estate activities with an eye toward increasing their individual wealth and prominence. And they succeeded. In 1870, approximately three years after starting the company, the median value of real estate and personal property owned by thirteen of sixteen in this group was $\$ 39,000$ and $\$ 10,000$, respectively (see table). ${ }^{38}$

Each entrepreneur rubbing shoulders with Hoyt commanded attention in the community, but a few were especially noteworthy. Benjamin F. Allen was by far the wealthiest. By 1870 , his $\$ 400,000$ in real estate and $\$ 1,644,000$ in personal property dwarfed the assets of the other Equitable founders. Allen had come to Des Moines from Indiana in 1848, bringing along the substantial sum of $\$ 15,000$ to invest. He opened a mercantile establishment, bought land extensively, engaged in banking with phenomenal success, and married. By 1860, his wealth already had risen to $\$ 130,000$ in real estate and $\$ 83,000$ in personal property. Citizens acknowledged Allen's prominence by sending him-over his protests-to the state senate and seeking his involvement in virtually every civic initiative. ${ }^{39}$

Frederick M. Hubbell, the youngest in the group, had conceived the idea to start a life insurance company and convened the founding session. The son of a prosperous stone mason and farmer, Hubbell came to Des Moines from Connecticut in 1855, when he was sixteen years old. He spent a few years in Sioux City, returned to Des Moines, and then rose from relative obscurity with stunning speed. Blessed with amazing energy and acute business instincts, he quickly mastered the practices of law, bill collection, and land speculation, especially the art of purchasing parcels at tax sales. Phineas M. Casady, who had given Hubbell his first job as a clerk in the United States land office and whose habit of assisting aspiring young men made

38. For a portrayal of the group founding Equitable of Iowa, see Pease, Patriarch of the Prairie, 8-14.

39. 1860 Manuscript Federal Census, Polk County, Iowa; Andrews, Pioneers of Polk County, 1:55-65. 


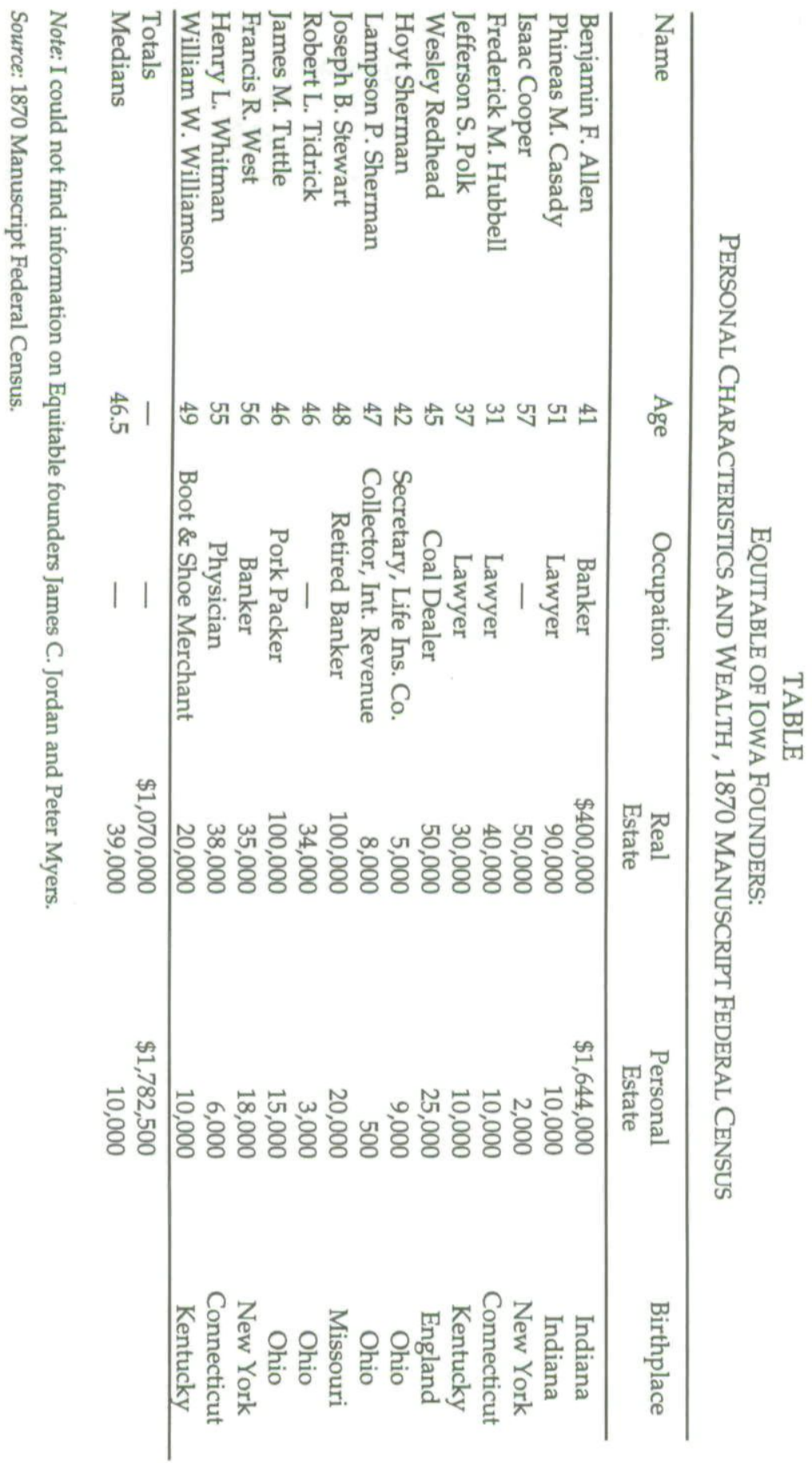


him something of a patriarch among the Equitable founders, invited Hubbell to become a partner in his law firm in 1862 . Years later, congratulating Casady on his eighty-ninth birthday, Hubbell recalled their first meeting in 1855, when Casady had employed him "after I had been refused a job at every store on Second Street, and Court Avenue." Hubbell acknowledged that the training he subsequently received in business in Casady's law firm had been "invaluable," and that the day he joined the firm "was the beginning of my career as a man of business." Hubbell failed to recollect that at the time of his entering the partnership he had driven hard to sweeten the deal, convincing Casady to accept three hundred dollars to make him a full partner immediately rather than after two years. Such assertiveness and ambition characterized Hubbell's career. ${ }^{40}$

Jefferson S. Polk, the third partner in Casady's law firm, remained in partnership with Hubbell after Casady withdrew in 1864 . He had come to Des Moines in 1855 from Kentucky. His personality grated on some, but his effectiveness as a lawyer secured him clients and profits. ${ }^{41}$ By 1860 , he held $\$ 5,000$ in real estate and \$500 in personal property. Like Hubbell, he stayed in Des Moines during the Civil War, forgoing the risks and potential glory of military service for business advancement. ${ }^{42}$

Although business elites coalesced to launch Equitable Life Insurance of Iowa, they did not always unite to promote other opportunities for community gain. In May 1872, a group led by Robert L. Tidrick, one of the Equitable founders and another early associate of Phineas M. Casady, outlined a framework for the "Citizens' Association of Des Moines." A by-laws committee articulated the association's objectives in proposed articles

40. Hubbell to Casady, 3 December 1907, Phineas M. Casady Papers, State Historical Society of Iowa, Des Moines; "Articles of copartnership made and entered into this 1st day of January 1862," Simon Casady Papers, box 1, file C, State Library of Iowa; Andrews, Pioneers of Polk County, 2:247-53; Mills, The Little Man with the Long Shadow, chaps., 1-6, 12.

41. Marcellus M. Crocker, a partner of Casady and Polk before becoming a Union officer at the start of the Civil War, complained that Polk "never alludes to me either publicly or privately without a sneer." Crocker to Casady, 25 April 1863, Simon Casady Papers, box 1, file C.

42. 1860 Manuscript Federal Census, Polk County, Iowa; Andrews, Pioneers of Polk County, 1:133-40. 
of incorporation: "To develop our resources, to encourage and assist in the improvement and material interest of our city, promote manufacturing and immigration, see that the money collected by taxes is judiciously and honestly expended, and influence legislation to amend or make laws to increase our commercial welfare and prosperity." Any citizen of Polk County could become a member by paying a three-dollar fee. The first fifty members were authorized to organize the association and elect officers. Eight standing committees-Finance, Manufactures, Home Manufactures, Taxes, Laws, Railroads, Publication, and Improvements-would function through the year, with an annual meeting of the membership scheduled for the first Tuesday in June. Over the next several weeks, instead of galvanizing the business community and matching the good results achieved by similar groups in other Iowa cities, the Citizens' Association of Des Moines became an emblem of local apathy. A "thinly attended" annual meeting in June 1873 forced the election of officers to be postponed. Attendance at the meeting the next week "was not so large as ... the demands of good citizenship required." The president of the association used his address to praise the few who had extended themselves and to condemn "the total indifference and coldness of a large proportion of our citizens." Hoyt Sherman followed with a motion to again postpone electing officers. No election took place, and the association died after a short and disappointing existence. ${ }^{43}$

Cleavage within the Des Moines business community became excruciatingly public following Benjamin F. Allen's catastrophic bankruptcy on January 19, 1875. Only six years earlier, Allen had hosted a gala opening for his magnificent home, Terrace Hill, on the western outskirts of Des Moines, deemed the most exquisite private residence west of the Mississippi River, and his lofty financial stature had seemed forever secure. All banks suffered to some degree during the depression that followed the Panic of 1873, but Allen, who enjoyed popular confidence for having weathered the downturn after the Panic of 1857, had given no indication of severe problems. Blame for the disaster came to rest on Allen's dubious in-

43. Iowa State Register, 24, 25, and 28 May 1872, 30 June 1872, 4 and 11 June 1873. 
volvement with the Cook County National Bank of Chicago, which had overcommitted his means and left him with insufficient liquidity or credit to meet calls for cash. Rumors also circulated about a "blanket mortgage" given to an eastern bank. Allen, who not long before had left Des Moines for Chicago to manage the Cook County National Bank, appended a brief note to the bankruptcy announcement assuring depositors that "no loss can occur to them-their payment being only a question of time. ${ }^{144}$

Allen's failure stunned people throughout Des Moines because his various financial institutions handled the deposits and mortgages of the small and modest as well as the great and mighty. Consternation seized Allen's many friends and creditors in Des Moines, and they waited anxiously for his return and a complete report of his assets and liabilities. Agonizing days passed until finally on February 5, at a gathering of approximately five hundred creditors and press representatives in Moore's Opera House, Allen presented the dismal condition of his financial affairs. He then "retired, desiring to leave the creditors entirely free to act as they saw fit, unbiased by his wishes or presence." ${ }^{\prime 45}$

Jefferson S. Polk demanded definite information from Allen about his plans for relieving creditors. When Allen could not comply, Polk offered a resolution for the creditors to file a petition of bankruptcy against Allen immediately. Polk feared that eastern interests holding two mortgages against Allen "would swallow up the greater portion of his assets" unless a trustee took charge of Allen's affairs until legal action could void the instruments that would leave local creditors with little or nothing. Polk's proposal drew opposition. The principal opponent argued that bankruptcy proceedings would involve "an immense amount of expense" and suggested that a committee of good businessmen working in conjunction with Allen would prove more satisfactory than turning the matter over to lawyers. Polk responded hotly through a "long and somewhat acrimonious debate," and, setting aside personal sentiments, resolutely

44. Ibid., 20-22, 24, and 27 January 1875.

45. Ibid., 6 February 1875. 
maintained that Allen should be detached from his assets. "I claim to be as good a friend of Mr. Allen as any here, but I do not wish to allow these New York and Chicago parties to come here and spirit away the assets. We cannot help Mr. Allen by delaying the matter. It is a fact that he has failed. . . . I say, this thing is much worse than it appears; worse than any of us had dreamed of. Let us not stand around here and do nothing actuated by false delicacy, but let us go to work and put ourselves in shape to protect our own interests." Polk won. The meeting accepted his original resolution to place Allen in bankruptcy and appointed a committee of five, including Polk and Hoyt Sherman, to implement the decision. Over the next several days the committee met creditors in a downtown Des Moines office and gathered proof of claims against Allen. ${ }^{46}$

A Chicago correspondent captured the split rending people in Des Moines: "the city may now be said to be divided into two distinct classes-those Mr. Allen owes constitute the larger class, and those who owe him, or are under obligations to him, constitute the other. The former class manifest for him a mingled spirit of friendship and contempt, and the latter are loud in their praises, not forgetting what he has done for them as individuals and for the advancement of the city at large." On February 23, the committee filed a bankruptcy petition in the United States District Court for the District of Iowa. On April 22 the court ruled Allen bankrupt; on July 22 the same court designated Hoyt Sherman as assignee of the estate. ${ }^{48}$

46. Ibid., 6, 7, 12 February 1875. A Chicago newspaper, whose correspondent had forced his way past guards allegedly "instructed to exclude Chicagoans," bitingly editorialized, "Mr. B. F. Allen's affairs are in a very desperate way. If the statement which he made to his creditors yesterday be interpreted by the ordinary rules, he is worse off than nothing. Counting in his available real estate at $\$ 1,204,615$, his bills receivable at $\$ 640,698.87$, and his stocks of various kinds at $\$ 426,972.45$, he is able to show a surplus of $\$ 837,828.46$. But it will be very surprising if any of these items realize the estimated amount. The real estate, in all probability, could not be sold to-day for half what it is put at; and it will be strange if the bills receivable of the broken bank do not show a large number of bad debts. That the statement was not satisfactory to the creditors of Mr. ALLEN is shown by the announcement of their intention to put him into bankruptcy." Chicago Tribune, 6 February 1875.

47. Chicago Tribune, 7 February 1875.

48. Polk County Archives, Property, 115:604-6. 
A contest of personalities, egos, and fortunes-virtually impossible to reconstruct-played out over a nine-year legal struggle to ascertain the fate of Allen's assets. From Polk's perspective, the mortgages held by eastern interests encumbering Allen's assets posed the gravest threat to Des Moines creditors, and Polk's persistence in the courts of New York and elsewhere finally obtained their invalidation. While Polk conducted this legal campaign, Hoyt Sherman, as assignee of Allen's astoundingly complex portfolio of assets, confronted innumerable management details and parried creditors pressing individual claims against the bankrupt Allen. He ultimately threw off the burden on June 25,1884 , by conveying all remaining assets to Polk and Hubbell for $\$ 350,000$. Law and business partners, and perhaps the most ambitious men in Des Moines, Polk and Hubbell had vied with Benjamin F. Allen for influence and fame. These two men now secured dominance in Des Moines business and social circles. Nothing signified the shift better than Hubbell's taking ownership of Allen's lavish Terrace Hill home. ${ }^{9}$

A few years after taking control of Allen's bankrupt estate, Polk and Hubbell dissolved their business partnership and competed against each other for local eminence. Polk reaped huge profits by consolidating the Des Moines street railways into an efficient system. In 1899 the tax rolls listed Polk's real estate at $\$ 300,000$, a figure that excluded the evidently taxexempt property related to his street railway company. Hubbell bested Polk, however, recording an extraordinary career as insurance president, land baron, and financial manager. A newspaper headline in 1899 proclaimed, "HUBBELL THE RICHEST MAN PAYS MORE TAXES THAN ANY ONE ELSE IN DES MOINES." Assessors valued Hubbell's local real estate holdings at $\$ 1,250,000$, but that formed only the part of his wealth that was readily tabulated; he also owned extensive bank stocks and a large share in Equitable Life Insurance Company. Assessor Frank French confessed that to determine Hubbell's real worth would

49. Chicago Tribune, 15 and 27 February and 6 March 1875; Iowa State Register, 6 and 7 February 1875; Polk County Archives, Property and Mortgages, 2:51-52, 15:279-80, 36:634-35, 30:58-59, 66:33; Des Moines Register and Leader, 4 November 1907. 


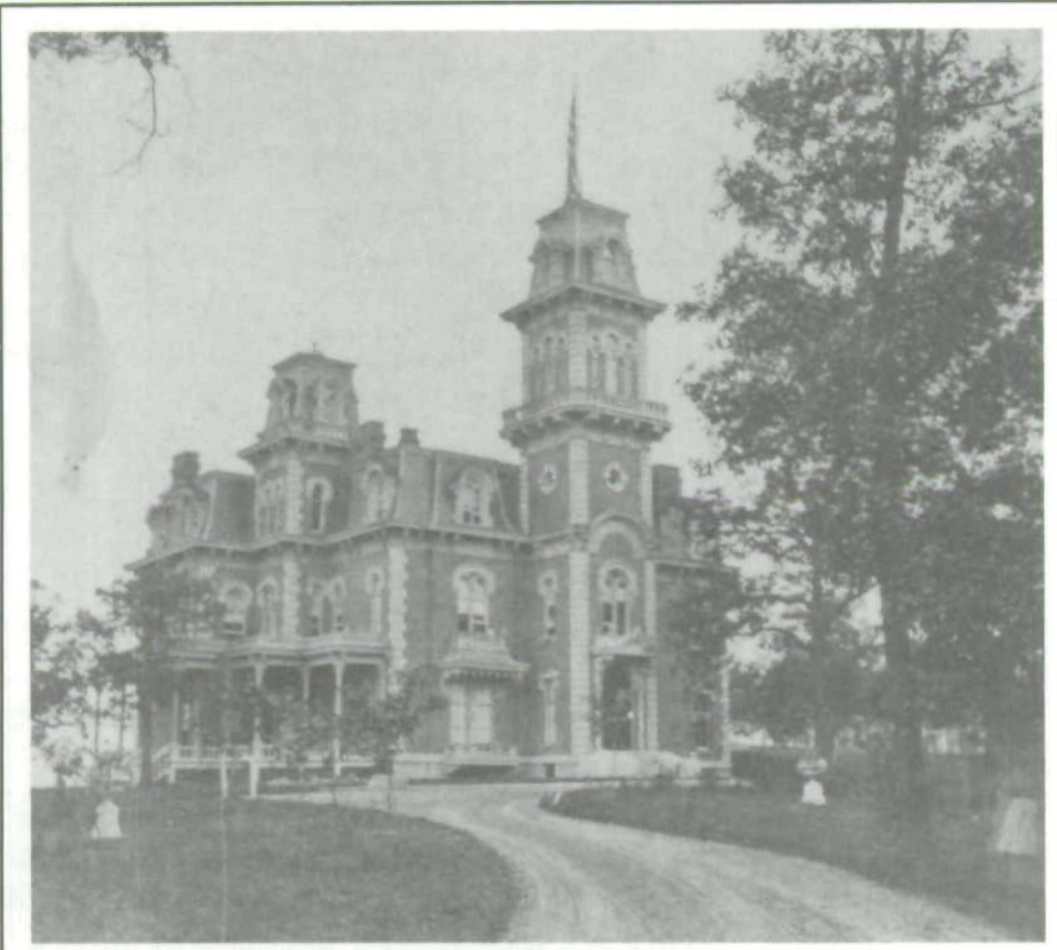

Terrace Hill in 1913, after it became the home of Frederick M. Hubbell. Courtesy State Historical Society of Iowa, Des Moines.

"require a man of greater genius in ferreting out and locating [assets] than he lays claim to in his line." ${ }^{\prime 50}$

Both men left rich estates upon their deaths. Polk died in 1907 , leaving a will devised on June 18,1906 , that carefully directed his executors to convert his extensive stock and real estate holdings into cash for distribution to the heirs after paying his debts. Polk's will contemplated that this would take five years. After diligent effort, the executors issued a final report on October 31, 1912, showing a dispensed surplus of more than a half-million dollars. Polk revealed something of his hard-boiled character in his will by continuing a forty-dollar monthly allowance to his brother that would terminate when the executors

50. Des Moines Register, 30 April 1899. 
directed him to enter "some good old people's home" that cost no more than forty dollars per month or he refused to observe the executor's wishes! An apparently wayward son likewise received unsentimental treatment in the will; he would be cut off from his inheritance if he alienated or assigned any of the inheritance to satisfy anyone who had taken legal action against him for debt. Hubbell died in 1930, but in late 1903 he had fashioned a trust fund that would safeguard his immense estate for his heirs for the remainder of the century. ${ }^{51}$

Allen came to a more melancholy end. He tried to recover his fortunes in Des Moines after his bankruptcy. He was listed in the city directory issued in 1884 as president of the Citizens Insurance Company of Iowa and in the one issued in 1886 as president of the Monarch Insurance Company. But about 1888 he left Des Moines to cultivate a small fruit farm in San Dimas, California, then a rather remote area east of Los Angeles. When Hoyt Sherman and other old friends invited him back in 1896 to celebrate the semicentennial of Polk County, Allen wrote plaintively without mentioning his bankruptcy, "From the day I first landed in Racoon Forks or Fort Des Moines, I always had great faith in its future greatness, and always predicted that Des Moines would grow to be the largest and most important city, in the great State of Iowa. You all know that in that I certainly was not mistaken. I wish I could find words to tell you what my heart would dictate of my recollections of those early days (I think the happiest of my life), but I find I cannot do it. I can only say my heart was with you all on July $8,1896 .{ }^{\prime 152}$

Others who had joined Polk and Hubbell in founding Equitable Life Insurance of Iowa ran into trouble over the remainder of their lives. Francis R. West, who had been associated with Allen in the banking business, suspended his own establishment in July 1877, and subsequent investigation showed to the astonishment of many "the utter hollowness of the shell

51. Jefferson S. Polk Probate, \#6207, Polk County Courthouse, Des Moines; Mills, The Little Man with the Long Shadow, 160-67.

52. Bushnell's Des Moines Directory, ... 1884-85 (Des Moines, 1884), 180; ibid., 1886-87 (Des Moines, 1886), 148; Semi-Centennial of the Organization of Polk County and Fort Des Moines, Iowa (Des Moines, 1896), 46. 
known as West \& Sons Bank." He never recovered his lost position. Wesley Redhead, an English immigrant who prospered through the $1850 \mathrm{~s}$ as a book and stationery dealer and postmaster before launching coal mining and other industrial enterprises, lost $\$ 15,000$ in West's failure. Praised for his benevolence and considered extremely wealthy despite vicissitudes through the years, Redhead died in 1891, leaving an estate with about $\$ 15,000$ in claims offsetting about $\$ 20,000$ in assets. ${ }^{53}$

Real estate often proved an uncertain asset. Henry L. Whitman, a physician who maintained good professional standing throughout his life, bequeathed $\$ 12,000$ to each of his three daughters. For decades after his death in 1885, Whitman's wife, executrix of the estate, tried without success to sell real estate at prices that would raise the designated sums. Finally, in 1912, the long since grown daughters acknowledged satisfactory discharge of their bequests. James C. Jordan, who lived beyond the limits of Des Moines and died in 1884 owning tracts of productive agricultural lands, granted bequests to his numerous children ranging from $\$ 2,100$ to $\$ 5,500$. Despite the largesse, at least one heir complained in 1895 that the executors mismanaged the properties to the detriment of the estate. ${ }^{54}$

Others were even more unfortunate. James M. Tuttle, Civil War veteran and once flourishing pork packer, died in 1892 in Arizona while engaged in a highly speculative mining venture. He left no will, a broken marriage, inconsequential personal property, and debts met only by selling his paltry real estate holdings. Robert L. Tidrick, associated with Phineas M. Casady as a land agent in the years immediately following settlement, died in 1894 with no general assets besides "bad notes" to five individuals amounting to $\$ 4,299$ and "good notes" to eight individuals totaling $\$ 5,048$. Though short on liquid assets, the estate administrator, Tidrick's sole surviving son, could report that "the debts against said Estate so far as known to him are

53. Iowa State Register, 19-22 July 1877; Wesley Redhead Probate, \#2265, Polk County Genealogical Society; Andrews, Pioneers of Polk County, 1:111-17, 159-63.

54. Henry L. Whitman Probate, \#1553; James C. Jordan Probate, \#2313, Polk County Genealogical Society. Some probates indicate that estates may have been diminished by earlier transfers of assets to relatives. 
very small and the property of the estate remaining more than ample to pay such debts."

Casady himself, noted land agent, lawyer, and banker, died in 1908. Surprisingly, he left no will. Although Casady had been rich in memories and friends, his estate reflected only modest means. He owned seven real estate parcels in "Original Fort Des Moines," $\$ 3,320$ in cash on deposit at the Iowa National Bank, and five shares of stock in the Capital City State Bank with a par value of $\$ 100$. The real estate earned $\$ 3,200$ in rents annually, and Casady's son Simon, who administered the estate, set aside $\$ 2,500$ per year to support the widow. $^{56}$

HOYT SHERMAN, too, clearly fell into the shadows of Polk and Hubbell, but his pride and restlessness kept him striving. ${ }^{57}$ Hoyt retired as president of Equitable Life Insurance of Iowa on January 18,1888 , selling his shares of Equitable stock at about the same time and enabling Hubbell, who assumed the presidency, to consolidate control of the company. Either with this cash or as part of a retirement deal with Hubbell, Hoyt paid off a $\$ 14,500$ mortgage held at 7 percent by Equitable and bought from Equitable a one-sixth portion of the original Sherman Block. Widowed in March 1887, Hoyt settled down after retirement to watch over his leased property in the business district, assist with charities, socialize in clubs and organizations such as the Pioneer Lawmakers' Association and the Grant Club, and write occasional historical pieces. ${ }^{58}$

55. James M. Tuttle Probate, \#2599; Robert L. Tidrick Probate, \#2969, Polk County Genealogical Society;

56. Phineas M. Casady Probate, \#6488, Polk County Courthouse.

57. A contemporary recalled Hoyt as "a man of high character, indomitable and gifted." Stiles, Recollections and Sketches, 468-69.

58. Polk County Archives, Property and Mortgages, 164:37, 199:595; Brigham, History of Des Moines, 1:563-65; Des Moines Leader, 15 February 1900; Pioneer Lawmakers' Association of Iowa, Reunion of 1904 . . . (Des Moines, 1904), 5, 50, 53; Iowa State Register, 3 March 1887. Rumors periodically surfaced that Hoyt had married more than once, prompting him to file a sworn affidavit on November 16, 1883, affirming that "I was married for the first and only time on the 25th day of December 1855." Polk County Archives, Property and Mortgages, 634:121. 
Unfortunately, his retirement years, when he usually called himself a capitalist, were unhappy. His oldest son, Frank, a lawyer in Des Moines, suffered business reverses that required Hoyt's financial assistance and died in 1902 after an extended period of ill health. Evidently in an attempt to raise cash in February 1893, Hoyt, with Frank's approval, conveyed his entire homestead property for $\$ 85,000$ to a developer named J. J. Burleigh, who subdivided the tract into twenty-five house lots. (It is unclear whether Hoyt actually realized the selling price.) The Panic of 1893 impeded sales, and the scheme collapsed, with the lots reverting to Equitable, from which Burleigh had negotiated a mortgage. During the next three difficult years, Hoyt lived in rentals at 619 Fourth Street and 600 Woodland Avenue and maintained an office with Frank in the prestigious Clapp Block. In 1897 Hoyt mortgaged other property to Northwestern Mutual Life Insurance for $\$ 40,000$ and worked out an arrangement to resume residence in his old homestead. Not until 1903, after another $\$ 15,000$ mortgage from Northwestern Mutual Life Insurance in 1901, did Hoyt regain legal ownership of his homestead from a moribund Sherman Place Land Company, which then owed bonds to Equitable totaling $\$ 76,000 . .^{59}$

Hoyt Sherman died at that home on January 25, 1904, leaving an estate nominally valued at $\$ 600,000$ on the strength of two long-term business property leases. In fact, the estate held cash assets of only a few thousand dollars, and cash liabilities, including notes against the homestead, far in excess of that amount. Executors wisely chose to put the two valuable business properties in trust and disperse the other real estate. Among these sales was the conveyance of the homestead for $\$ 500$ and assumption of outstanding mortgages to the Board of Park Commissioners of Des Moines. ${ }^{60}$ Hoyt Sherman, like so

59. Iowa State Register, 5 March 1902; Frank A. Sherman Probate File, Polk County Genealogical Society; Polk County Archives, Property and Mortgages, 262:374-75, 296:217-20, 313:167, 168, 178, 323:302, 363:257-58, 409:264-68, 455:215-16; Des Moines Directory, 1894, 584; R. L. Polk \& Co.'s Des Moines ... Directory, 1895 (Des Moines), 537; ibid., 1896 (Des Moines, 1896), 524; Des Moines Directory, 1897, 518.

60. Hoyt Sherman Probate, \#5073, Polk County Genealogical Society; Polk County Archives, Property and Mortgages, 475:550, 510:212-13, 532:110, 543:183-86. 


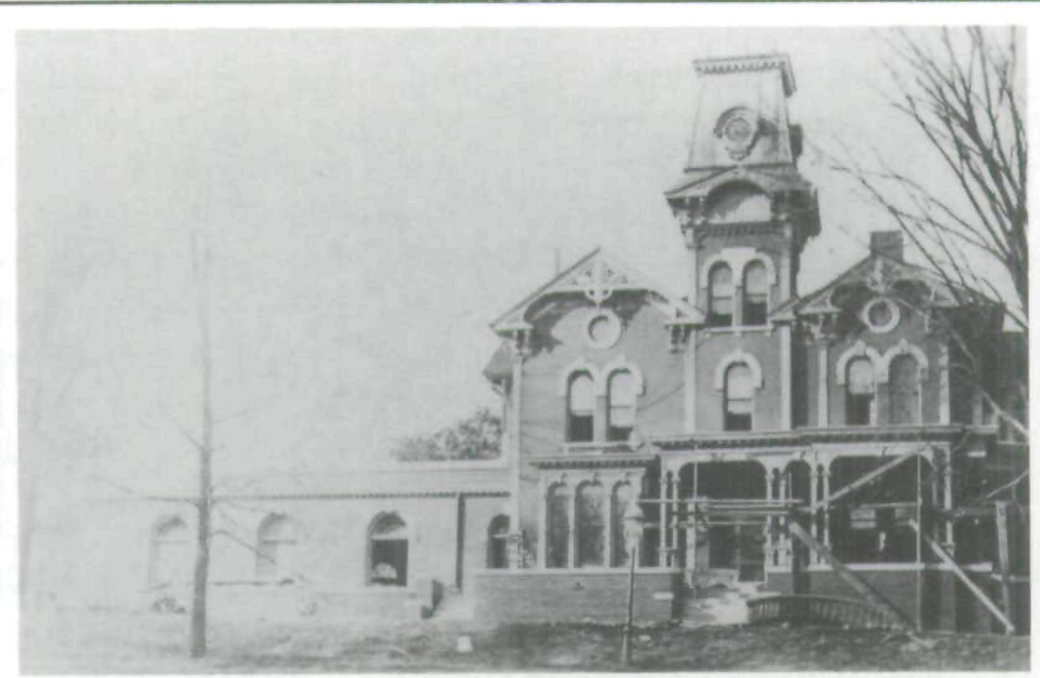

Hoyt Sherman Place. Photo, courtesy State Historical Society of Iowa, Des Moines, taken as the Des Moines Woman's Club was overseeing the renovation and expansion of the building.

many of his business contemporaries, never trusted any investment but real estate. His unwillingness to deal in stocks, bonds, and other dynamic but risky financial instruments made it almost impossible for him to build a genuine fortune or compete with the most aggressive business actors of the late nineteenth century.

THE EXPERIENCES of James, Lampson P., and Hoyt Sherman reveal the uncertainty, complexity, and competitiveness of life in Des Moines as the city developed between 1850 and 1900 and suggest the experiences of many of their contemporaries among the dispossessed, the burgher, and the entrepreneurial layers of the community. Personal choices set individuals in certain directions, but limitations of character and temperament, decisions and ambitions of other individuals, physical and economic circumstances beyond one's control, and simple fate could dramatically influence final destinations. ${ }^{61}$ Those

61. Timothy Mahoney reaches a related conclusion in "Down in Davenport." 
among the dispossessed endured the harshest trials, and burghers carefully minimized risk, but potential for failure lurked ominously and ubiquitously regardless of one's relative status. Within the entrepreneurial layer, competition was fierce and much more commonplace than cooperation. As demonstrated by the Equitable Life founders, a startling number of the pioneer businessmen deemed wealthy and successful died in circumstances ranging from exceedingly modest to actual want. A "Darwinian" struggle to determine the most fit, or, in some cases, the most fortuitous, may most aptly describe Des Moines during this period. ${ }^{62}$

Why competitiveness flourished so vibrantly in Des Moines during its formative years defies precise explanation, but clearly the forceful personalities and shrewdness of men such as Frederick M. Hubbell and Jefferson S. Polk played a role larger than any structural features that differentiated Des Moines from midwestern cities with more evidence of cooperation among their entrepreneurial layer. More research into the relationship between business elites and local city government probably would suggest other answers to this question, and research into women and their networks in Des Moines would offer additional insight. ${ }^{63}$

The Sherman brothers, like others in Des Moines and elsewhere, knew loss, sorrow, frustration, anger, and pain as well as joy, love, satisfaction, and fulfillment. Recovering their lives and those of contemporaries in multiple dimensions makes these people more human and more interesting while revealing the fundamental layers of economic and social life in Des Moines during the years when an important city emerged from a frontier fort.

62. A study of merchants in San Francisco during the same period found debilitating competitiveness and pervasive disillusionment and concluded that even "the advantages of native blood, an adequate bank account, and a few well-placed business and family connections ... did not by any means guarantee success; they only lowered the odds against failure." Peter R. Decker, Fortunes and Failures: White-Collar Mobility in Nineteenth-Century San Francisco (Cambridge, MA, 1978), 252.

63. Louise R. Noun, Strong-Minded Women: The Emergence of the Woman-

Suffrage Movement in Iowa (Ames, 1969), provides a starting point. 
Copyright of Annals of Iowa is the property of State of Iowa, by \& through the State Historical Society of Iowa and its content may not be copied or emailed to multiple sites or posted to a listserv without the copyright holder's express written permission. However, users may print, download, or email articles for individual use. 